\title{
Bacterial genus is a risk factor for major amputation in patients with diabetic foot
}

\section{Gênero bacteriano é fator de risco para amputação maior em pacientes com pé diabético}

Natália Anício Cardoso"; Lígia de loiola Cisneiros²; Carla Jorge Machado²; Juliana Merlin Cenedezi²; Ricardo Jayme Procópio3,4; Túlio PinHo NAVARRO ${ }^{2-4}$.

\section{A B S T R A C T}

\begin{abstract}
Objective: to evaluate whether bacterial genus is a risk factor for major amputation in patients with diabetic foot and infected ulcer. Methods: we conducted a case-control, observational study of 189 patients with infected ulcers in diabetic feet admitted to the Vascular Surgery Service of the Risoleta Tolentino Neves Hospital, from January 2007 to December 2012. The bacteriological evaluation was performed in deep tissue cultures from the lesions and amputation was considered major when performed above the foot'smiddle tarsus. Results: the patients'mean age was $61.9 \pm 12.7$ years; 122 (64.6\%) were men. The cultures were positive in $86.8 \%$, being monomicrobial in $72 \%$ of the cases. In patients with major amputation, Acinetobacter spp. (24.4\%), Morganella spp. (24.4\%), Proteus spp. (23.1\%) and Enterococcus spp. (19.2\%) were the most frequent types of bacteria. The most commonly isolated species were Acinetobacter baumannii, Morganella morganii, Pseudomonas aeruginosa and Proteus mirabilis. As predictors of major amputation, we identified the isolation of the generaAcinetobacter spp. and Klebsiella spp., serum creatinine $\geq 1.3 \mathrm{mg} / \mathrm{dl}$ and hemoglobin $<11 \mathrm{~g} / \mathrm{dl}$. Conclusion: the bacterial genera Acinetobacter spp. and Klebsiella spp. identified in infected ulcers of patients with diabetic foot were associated with a higher incidence of major amputation.
\end{abstract}

Keywords: Diabetic Foot. Foot Ulcer. Infection. Amputation.

\section{INTRODUCTION}

$T_{\text {hes }}^{\text {he }}$ he diabetic foot disease is the major cause of hospitalization and costs for diabetic patients. It is a major public health problem, since diabetes mellitus affects about 415 million people worldwide ${ }^{1-3}$. Patients with diabetic foot present high rates of amputation, with a 25 -fold higher risk when compared to patients without diabetes ${ }^{3}$. About $40 \%$ to $60 \%$ of non-traumatic lower limb amputations performed worldwide are due to diabetes complications, and $80 \%$ of such amputations are preceded by foot ulcers ${ }^{4,5}$. Foot ulcers will occur in approximately $25 \%$ of diabetic ${ }^{6}$.

Among the clinical conditions associated with diabetic foot, such as neuropathy, deformities and ischemia, and comorbidities such as advanced age, heart disease, coronary disease, cerebrovascular disease, renal insufficiency and respiratory failure, ulcer infection is associated with higher mortality and high rates of lower limb amputation 7,8 . About $40 \%$ to $80 \%$ of ulcers in diabetic patients progresses with infection and this is considered a clinical marker of systemic impairment and high mortality ${ }^{4,9,10}$. Superficial and acute infections are usually monomicrobial and caused by Gram-positive aerobic cocci, mainly staphylococci and/ or streptococci1,6,9,11. In deep, chronic or complicated infections, there is predominance of Gram-negative bacteria $^{8}$. They are polymicrobial in 60 to $80 \%$ of cases, with Gram-positive (Staphylococcus spp., Streptococcus spp. and Enterococcus spp.), Gram-negative (Glucosefermenting bacilli of the Enterobacteriacea family and non-glucose fermenters, such as Pseudomonas spp. and Acinetobacter spp.) and anaerobic (mainly Bacteroides) $)^{6,9}$. It is important to verify if the bacterial genus isolated in infected diabetic foot ulcers is a predictive factor of lower limb amputation.

This study aims to evaluate whether the bacterial genus is a risk factor for amputation in patients

1 - Federal University of Minas Gerais, Post-Graduate Program in Applied Sciences for Surgery and Ophthalmology, Faculty of Medicine, Belo Horizonte, Minas Gerais State, Brazil. 2 - Federal University of Minas Gerais, Faculty of Medicine, Belo Horizonte, Minas Gerais State, Brazil. 3 - Risoleta Tolentino Neves Hospital, Vascular Surgery Service, Belo Horizonte, Minas Gerais State, Brazil. 4 - Clinics Hospital, Federal University of Minas Gerais, Vascular Surgery Service, Belo Horizonte, Minas Gerais State, Brazil. 
with diabetic foot and infected ulcers. Secondarily, it aims to verify if polymicrobial infection and reinfection also correlate with major amputation.

\section{METHODS}

We conducted a case-control, observational study of 189 patients with infected diabetic foot ulcers admitted to the Vascular Surgery Service of Risoleta Tolentino Neves Hospital, a tertiary university hospital in Belo Horizonte, Minas Gerais State, Brazil, from January 2007 to December 2012. All patients had a deep tissue bacteriological culture. We excluded patients who had the collection of biological material with swab and who underwent minor amputation. We considered a minor amputation when performed below the middle tarsus of the foot, and major, when above the middle tarsus.

The ulcers analyzed were all deep and were graded according to the Wagner Classification as $\geq 3$, which corresponds to ulcers that compromise deep tissues. We considered as negative cultures where there was no bacterial growth. Those with growth of two or more bacteria, we considered polymicrobial. We considered as reinfection cultures where there was growth of bacteria of different species in cultures carried out at different periods.

We collected the following variables after access to patients' electronic records: age, gender, surgeries, death, serum hemoglobin and creatinine levels, and bacteriological (genus and species) results.

The case group consisted of patients who underwent major amputation and the control group, of patients who did not.

For statistical analysis, was used the Stata/ SE 12.0 software for Mac. We expressed continuous variables as mean and standard deviation, and analyzed them using the Student's t-test. We assessed categorical variables with the Pearson's chi-square or Fisher's test (if the expected number of cases in a category were less than five). We determined the predictive factors for major amputation by means of logistic regression analyzes. Values that were statistically significant in the Wald test (univariate analysis) were included in a multivariate model and the final model was obtained by sequential deletion of variables, based on the Wald and Hosmer and Leme show tests. We measured the statistical significance of the final model by the Hosmer and Leme show test $(p<0.05)$.

Table1. Comparison of the different studied variables between groups of patients.

\begin{tabular}{|c|c|c|c|c|}
\hline & \multicolumn{4}{|c|}{ Major Amputation } \\
\hline & $\begin{array}{c}\text { Total } \\
(\mathrm{n}=189)\end{array}$ & $\begin{array}{c}\text { Yes } \\
(n=78)\end{array}$ & $\begin{array}{c}\text { No } \\
(n=111)\end{array}$ & $p$-value \\
\hline Average age in years (SD) & $61.9( \pm 12.7)$ & $63.8( \pm 10.5)$ & $60.6( \pm 13.9)$ & 0.0895 \\
\hline Males, n (\%) & $122(64.6)$ & $54(69.2)$ & $68(61.3)$ & 0.259 \\
\hline Average of highest serum creatinine level (SD) & $1.95( \pm 1.8)$ & $2.49( \pm 2.4)$ & $1.57( \pm 1.1)$ & $<0.001 * * *$ \\
\hline Average of lowest serum hemoglobin level (SD) & $8.93( \pm 2.6)$ & $7.35( \pm 1.7)$ & $10.0( \pm 2.5)$ & $<0.001 * * *$ \\
\hline \multicolumn{5}{|l|}{ Cultures undergone by patients, n (\%) } \\
\hline $\begin{array}{l}1 \text { culture } \\
2 \text { cultures } \\
>2 \text { cultures }\end{array}$ & $\begin{array}{l}120(63.5) \\
43(22.8) \\
26(13.8)\end{array}$ & $\begin{array}{l}42(53.9) \\
21(26.9) \\
15(19.2)\end{array}$ & $\begin{array}{c}78(70.3) \\
22(19.8) \\
11(9.9)\end{array}$ & 0.054 \\
\hline Patients with positive cultures, n (\%) & $164(86.8)$ & $68(87.2)$ & $96(86.5)$ & 0.890 \\
\hline Patients with polymicrobial cultures, n (\%) & $53(28.0)$ & $25(32.1)$ & $28(25.2)$ & 0.304 \\
\hline Patients with reinfection, n (\%) & $40(21.2)$ & $24(30.8)$ & $16(14.4)$ & $0.007 * *$ \\
\hline Hospital readmission, n (\%) & $81(42.9)$ & $37(47.4)$ & $44(39.6)$ & 0.286 \\
\hline Mortality n (\%) & 30 (15.9) & $18(23.1)$ & $12(10.8)$ & 0.023 * \\
\hline
\end{tabular}

Notes: ${ }^{*} p<0.05 ;{ }^{*} p<0.01 ; p<0.001 ;$ SD: Standard Deviation. 
Table 2. Comparison between the groups of patients according to the bacterial genera isolated in deep tissue cultures.

\begin{tabular}{|c|c|c|c|c|}
\hline & \multicolumn{4}{|c|}{ Major Amputation } \\
\hline & $\begin{array}{c}\text { Total } \\
(n=189)\end{array}$ & $\begin{array}{c}\text { Yes } \\
(n=78)\end{array}$ & $\begin{array}{c}\text { No } \\
(n=111)\end{array}$ & $\mathrm{p}$ \\
\hline \multicolumn{5}{|l|}{ Gram-positive genera } \\
\hline Enterococcusspp. n (\%) & $28(14.8)$ & $15(19.2)$ & $13(11.7)$ & 0.152 \\
\hline Staphylococcusspp. n (\%) & $30(15.9)$ & $8(10.3)$ & $22(19.8)$ & 0.077 \\
\hline Streptococcusspp. n (\%) & $12(6.4)$ & $4(5.1)$ & $8(7.2)$ & 0.764 \\
\hline \multicolumn{5}{|l|}{ Gram-negative genera } \\
\hline Acinetobacterspp. n (\%) & $27(14.3)$ & $19(24.4)$ & $8(7.2)$ & $0.001 * *$ \\
\hline Citrobacterspp. n (\%) & $9(4.8)$ & $4(5.1)$ & $5(4.5)$ & 0.999 \\
\hline Escherichia spp. n (\%) & $27(14.3)$ & $9(11.5)$ & $18(16.2)$ & 0.366 \\
\hline Enterobacterspp. n (\%) & $20(10.6)$ & $9(11.5)$ & $11(9.9)$ & 0.720 \\
\hline Klebsiellaspp. n (\%) & $8(4.2)$ & $6(7.7)$ & $2(1.8)$ & 0.067 \\
\hline Morganellaspp. n (\%) & 35 (18.5) & $19(24.4)$ & $16(14.4)$ & 0.083 \\
\hline Proteusspp. n (\%) & 35 (18.5) & $18(23.1)$ & $17(15.3)$ & 0.176 \\
\hline Pseudomonasspp. n (\%) & $37(19.6)$ & $13(16.7)$ & $24(21.6)$ & 0.398 \\
\hline Serratiaspp. n (\%) & $5(2.7)$ & $4(5.1)$ & $1(0.9)$ & 0.094 \\
\hline Stenotrophomonasspp. n (\%) & $2(1.1)$ & $1(1.3)$ & $1(0.9)$ & 0.999 \\
\hline
\end{tabular}

Notes: ${ }^{* *} p<0.01$. The frequencies were calculated based on the total sample of 189 patients.

This study was approved by the Ethics in Research Committee of the Federal University of Minas Gerais (CAEE: 33623414.6.0000.5149) and authorized by the Nucleus of Education, Research and Extension of the hospital where the study was conducted.

\section{RESULTS}

Table 1 brings the data regarding the total and per group samples, as well as their comparison.

The mean patients'age was 61.9 years $( \pm 12.7)$, and 122 (64.6\%) were males. Patients who underwent major amputation had a higher mean serum creatinine level, $2.49 \mathrm{mg} / \mathrm{dl}( \pm 2.4)$, and a lower mean serum hemoglobin level, $7.35 \mathrm{~g} / \mathrm{dl}$ $( \pm 1.7)$, compared with patients who did not undergo amputation. Regarding hospitalization, $57.1 \%$ of the patients were hospitalized only once, while 81 $(42.9 \%)$ had to be admitted more than once. The hospital mortality in the study period was $15.9 \%$, and it was higher among patients submitted to major amputation $(23.1 \%)$ than those who did not undergo amputation (10.8\%).

Of the 189 patients, 164 (86.8\%) had positive cultures; 120 (63.5\%) had only one deep tissue bacteriological culture, while 43 (22.8\%) had two and 26 (13.8\%), more than two cultures during the hospitalization period. Among the 164 patients with positive cultures, $72 \%$ presented monomicrobial cultures and $28 \%$, polymicrobial ones. There was reinfection in $21.2 \%$ of patients.

The most commonly isolated bacteria in the samples of the patients who underwent major amputation were Acinetobacter spp. (24.4\%), Morganella spp. (24.4\%), Proteus spp. (23.1\%) and Enterococcus spp. (19.2\%). Acinetobacter spp.was the most frequent isolate from patients undergoing amputation when compared with patients not submitted to it.

The most frequent species in the samples of the patients who underwent major amputation were, in descending order, Acinetobacter baumannii, Morganella morganii, Pseudomonas aeruginosa and Proteus mirabilis. 
Of the 23 variables analyzed in Tables 1 and 2 , five were predictive factors associated with increased amputation risk, as observed in Table 3. These were: serum creatinine levels $\geq 1.3 \mathrm{mg} / \mathrm{dl}$, serum hemoglobin levels $<11 \mathrm{~g} / \mathrm{dl}$, rate of reinfection, mortality and isolation of Acinetobacter spp.in the infected ulcers.

On the other hand, the multivariate logistic model revealed that major amputation was independently and positively associated with serum hemoglobin levels $<11 \mathrm{~g} / \mathrm{dl}$, serum creatinine levels $>1.3 \mathrm{mg} / \mathrm{dl}$ and growth, in deep tissue cultures, of Acinetobacter spp. and Klebsiella spp.(Table 4). We should note that polymicrobial culture and reinfection were not predictive of major amputation.

\section{DISCUSSION}

Although diabetic patients have many serious comorbidities, infected ulcer is considered a risk factor for major amputation ${ }^{7,8}$. In the studied sample, the isolation of the bacterial genera Klebsiella spp. and Acinetobacter spp. was a predictive factor for major amputation. These bacteria are associated with nosocomial infections and are considered opportunistic pathogens. They cause infection, especially in patients with low immunity or who have undergone invasive procedures, characteristic of the patients studied. In addition, these microorganisms can develop antimicrobial resistance, which makes it difficult to treat the infection and, therefore, may increase the amputation risk ${ }^{12,13}$.

The microbiological profile of the sample studied had a predominance of Gram-negative bacteria. Isolation of Gram-negative bacteria, observed in $66 \%$ of deep lesions' cultures (Wagner Classification $\geq 3$ ), was also more frequent in a study carried out at the Central Hospital of the São Paulo Holy Home ${ }^{14}$.

In our sample, $86.8 \%$ of the patients had bacterial isolation in deep tissue cultures. We thus

Table 3. Univariate analysis of 23 the clinical and bacteriological variables.

\begin{tabular}{lccc}
\hline & Odds Ratio & 95\% Confidence Interval & $P$ \\
\hline Age, by year & 1.02 & $0.99-1.05$ & 0.091 \\
Gender, male & 0.70 & $0.38-1.30$ & 0.260 \\
Creatinine $\geq 1.3 \mathrm{mg} / \mathrm{dL}$ & 2.26 & $1.25-4.09$ & $0.007 * *$ \\
Hemoglobin $<11 \mathrm{~g} / \mathrm{dL}$ & 0.55 & $0.46-0.67$ & $<0.001 * * *$ \\
Positive cultures & 1.06 & $0.45-2.51$ & 0.890 \\
Polymicrobial cultures & 1.40 & $0.74-2.65$ & 0.305 \\
Reinfection & 2.64 & $1.29-5.40$ & $0.008 * *$ \\
Rehospitalization & 1,37 & $0.77-2.47$ & 0.287 \\
Mortality & 2.48 & $1.11-5.50$ & 0.026 \\
Acinetobacterspp. & 4.15 & $1.71-10.05$ & $0.002 * *$ \\
Citrobacterspp. & 1.15 & $0.30-4.41$ & 0.843 \\
Escherichia spp. & 0.67 & $0.29-1.59$ & 0.368 \\
Enterococcusspp. & 1.79 & $0.80-4.02$ & 0.156 \\
Enterobacterspp. & 1.19 & $0.47-3.01$ & 0.720 \\
Klebsiellaspp. & 4.54 & $0.89-23.13$ & 0.068 \\
Morganellaspp. & 1.91 & $0.91-4.01$ & 0.086 \\
Proteusspp. & 1.66 & $0.79-3.47$ & 0.179 \\
Pseudomonasspp. & 0.73 & $0.34-1.53$ & 0.399 \\
Staphylococcusspp. & 0.46 & $0.19-1.10$ & 0.081 \\
Serratiaspp. & 5.95 & $0.65-54.26$ & 0.114 \\
Stenotrophomonasspp. & 1.43 & $0.09-23,19$ & 0.802 \\
Streptococcusspp. & 0.70 & $0.20-2.40$ & 0.566 \\
\hline Not: $<0.05 * p<0.010$ & & &
\end{tabular}

Notes: ${ }^{*} p<0.05 ;{ }^{* *} p<0.01 ; p<0.001$. 
Table 4. Multivariate analysis of the variables associated with major amputation.

\begin{tabular}{lccc}
\hline & Odds Ratio & 95\% confidence interval & p-value \\
\hline Creatinine $\geq 1.3 \mathrm{mg} / \mathrm{dL}$ & 1.23 & $0.99-1.52$ & 0.053 \\
Hemoglobin $<11 \mathrm{~g} / \mathrm{dL}$ & 20.5 & $4.30-97.4$ & $<0.001$ \\
Acinetobacterspp. & 3.32 & $1.25-8.77$ & 0.016 \\
Klebsiellaspp. & 9.82 & $0.96-100.7$ & 0.054 \\
\hline
\end{tabular}

observed negative cultures in $13.2 \%$ of the patients, probably due to the use of antibacterials prior to the collection of biological material, which occurred with many of our patients previously treated in other health units ${ }^{8}$.

Studies indicate that diabetic foot infections are polymicrobial in nature ${ }^{6,9}$. In this study, polymicrobial culture was not a risk factor for major amputation, since monomicrobial cultures prevailed (72\%). Other authors also observed the predominance of the isolation of only one bacterial species in diabetic foot ulcers deep tissue cultures ${ }^{1,15-17}$. Some factors may have contributed to obtaining these monomicrobial cultures: 1) In ulcers with a short evolution time, monomicrobial isolation prevails ${ }^{16}$. In this study, we cannot safely determine the ulcers'evolution time. 2) Patients who use antibacterial agents before collecting the biological sample for culture may have altered results, as treatment-sensitive bacteria are eliminated, persisting antibacterial-resistant bacteria that are then isolated. As previously reported, many patients may have been admitted to the institution after previous antibiotic treatment. Finally, in severe ulcer infections, anaerobic bacteria can be isolated ${ }^{9}$. The institution's microbiology laboratory carries out cultures only for facultative anaerobes, and these cultures are mainly required in cases of osteomyelitis. In this sample, we found no records of facultative anaerobes in cultures.

In this study, 40 (21.2\%) patients presented with ulcer reinfection, which was not a risk factor for major amputation. However, among the patients undergoing amputation, 30.8\% had reinfection, where as among the non-amputation patients, the reinfection rate was $14.4 \%(p=0.007)$. Reinfected ulcers may display delayed healing, which may increase the risk of limb amputation ${ }^{18}$.
In addition to the microbiological profile, we identified other factors associated with major amputation. A serum hemoglobin level of less than $11 \mathrm{~g} / \mathrm{dl}$ was one such risk factor. One-fourth of diabetic patients have anemia ${ }^{19}$. It is believed that the association of anemia with increased amputation is due to decreased tissue oxygenation, which can lead to difficulties in healing and infection control ${ }^{15,20}$.

A serum creatinine level equal to or greater than $1.3 \mathrm{mg} / \mathrm{dl}$ was also a risk factor for major amputation. Diabetes mellitus is one of the leading causes of chronic kidney disease, which manifests in about 20 to $40 \%$ of diabetic patients ${ }^{21}$. Ulcer healing is prolonged with increased serum creatinine, which increases the risk of amputation ${ }^{22-24}$.

In this study, patients who underwent major amputation (23.1\%) had a higher hospital mortality compared with patients not submitted to amputation $(10.8 \%, p=0.023)$. The overall hospital mortality was $15.9 \%$ and is related to the various comorbidities and complications that these patients present, such as heart disease, coronary disease, cerebrovascular disease, renal failure, respiratory failure and peripheral arterial disease.

In this sample, patients with a mean age greater than 60 years and males (64.6\%) predominated, but there were no differences regarding the risk of infection in relation to genderor age.

Eighty-one (42.9\%) patients returned to the institution, most of them due to infectious complications related to the amputation. However, this high rehospitalization rate was not associated with major amputation, though increasing morbidity and costs.

Among the limitations of this study are the fact that it is retrospective, the limitation of the laboratory in performing cultures for strict anaerobes 
and the collection of material for culture in patients possibly using antibacterials prior to hospitalization.

In conclusion, the bacterial genera Acinetobacter spp. and Klebsiella spp. identified in infected ulcers of patients with diabetic foot were associated with major amputation. In addition, serum creatinine levels $\geq 1.3 \mathrm{mg} / \mathrm{dl}$ and hemoglobin $<11 \mathrm{~g} / \mathrm{dl}$ werealsorisk factorsformajor amputation. Nevertheless, polymicrobial cultures and ulcerreinfection did not influence the level of amputation.

\title{
R E S U M O
}

\begin{abstract}
Objetivo: avaliar se gênero bacteriano é fator de risco para amputação maior em pacientes com pé diabético e úlcera infectada. Método: estudo observacional do tipo caso-controle de 189 pacientes com úlcera infectada em pé diabético admitidos pelo Serviço de Cirurgia Vascular do Hospital Risoleta Tolentino Neves, no período de janeiro de 2007 a dezembro de 2012. A avaliação bacteriológica foi realizada em cultura de tecido profundo das lesões e a amputação foi considerada como maior quando realizada acima do médio tarso do pé. Resultados: a média de idade dos pacientes foi $61,9 \pm 12,7$ anos e $122(64,6 \%)$ eram homens. As culturas foram positivas em $86,8 \%$, sendo monomicrobianas em $72 \%$ dos casos. Nos pacientes com amputação maior, os gêneros de bactérias mais frequentes foram Acinetobacter spp. (24,4\%), Morganella spp. (24,4\%), Proteus spp. (23,1\%) e Enterococcus spp. (19,2\%) e as espécies mais isoladas foram Acinetobacter baumannii, Morganella morganii, Pseudomonas aeruginosa e Proteus mirabilis. Identificou-se como fatores preditivos para amputação maior o isolamento dos gêneros Acinetobacter spp. e Klebsiella spp.,e níveis séricos de creatinina $\geq 1,3 \mathrm{mg} / \mathrm{dl}$ e de hemoglobina <11 g/dl. Conclusão: os gêneros bacterianos Acinetobacter spp. e Klebsiella spp. identificados nas úlceras infectadas dos pacientes com pé diabético associaram-se a maior incidência de amputação maior.
\end{abstract}

Descritores: Pé Diabético. Úlcera do Pé. Infecção. Amputação.

\section{REFERENCES}

1. Hadadi A, Omdeh Ghiasi H, Hajiabdolbaghi M, Zandekarimi M, Hamidian R. Diabetic foot: infections and outcomes in Iranian admitted patients. Jundishapur J Microbiol. 2014;7(7):e11680.

2. Martins-Mendes D, Monteiro-Soares M, Boyko EJ, Ribeiro M, Barata P, Lima J, et al. The independent contribution of diabetic foot ulcer on lower extremity amputation and mortality risk. J Diabetes Complications. 2014;28(5):632-8.

3. International Diabetes Federation. IDF Diabetes Atlas. 7th ed. Brussels, Belgium: International Diabetes Federation; 2015.

4. Amaral Júnior $A H$, Amaral LAH, Bastos $M G$, Nascimento LC, Alves MJM, Andrade MAP. Prevention of lower-limb lesions and reduction of morbidity in diabetic patients. Rev bras ortop. 2014;49(5):482-7.

5. Hingorani A, LaMuraglia GM, Henke P, Meissner $\mathrm{MH}$, Loretz $\mathrm{L}$, Zinszer KM, et al. The management of diabetic foot: A clinical practice guideline by the Society for Vascular Surgery in collaboration with the American Podiatric Medical Association and the Society for Vascular Medicine. J Vasc Surg. 2016;63(2 Suppl):3s-21s.

6. Spichler A, Hurwitz BL, Armstrong DG, Lipsky BA. Microbiology of diabetic foot infections: from Louis
Pasteur to 'crime scene investigation'. BMC Med. 2015;13:2.

7. Mills JL, Sr., Conte MS, Armstrong DG, Pomposelli FB, Schanzer A, Sidawy AN, et al. The Society for Vascular Surgery Lower Extremity Threatened Limb Classification System: risk stratification based on wound, ischemia, and foot infection (W/fI). J Vasc Surg. 2014;59(1):220-34.e1-2.

8. Turhan V, Mutluoglu M, Acar A, Hatipoglu M, Onem $Y$, Uzun $G$, et al. Increasing incidence of Gram-negative organisms in bacterial agents isolated from diabetic foot ulcers. J Infect Dev Ctries. 2013;7(10):707-12.

9. Akhi MT, Ghotaslou R, Asgharzadeh M, Varshochi M, Pirzadeh T, Memar MY, et al. Bacterial etiology and antibiotic susceptibility pattern of diabetic foot infections in Tabriz, Iran. GMS Hyg Infect Control. 2015;10:Doc02.

10. Perim MC, Borges Jda C, Celeste SR, Orsolin Ede F, Mendes RR, Mendes GO, et al. Aerobic bacterial profile and antibiotic resistance in patients with diabetic foot infections. Rev Soc Bras Med Trop. 2015;48(5):546-54.

11. Lipsky BA, Aragon-Sanchez J, Diggle M, Embil J, Kono S, Lavery L, et al. IWGDF guidance on the diagnosis and management of foot infections in persons with diabetes. Diabetes Metab Res Rev. 2016;32 Suppl 1:45-74. 
12. Martins AF, Barth AL. Acinetobacter multirresistente - um desafio para a saúde pública. Sci Med. 2013;23(1):56-62.

13. Scarpate ECB, Cossatis JJ. A presença da Klebsiella pneumoniae produtora de B-lactamase de espectro estendido no ambiente hospitalar. Saúde \& Ambiente em Revista. 2009;4(1):1-11.

14. Ohki AV, Galvão RC, Marques CG, Santos VP, Casteli Júnior V, Caffaro RA. Perfil microbiológico nas infecções profundas do pé diabético. Arq Med Hosp Fac Ciênc Med Santa Casa São Paulo. 2010;55(1):15-7.

15. Aziz Z, Lin WK, Nather A, Huak CY. Predictive factors for lower extremity amputations in diabetic foot infections. Diabet Foot Ankle. 2011;2.

16. Banu A, Noorul Hassan MM, Rajkumar J, Srinivasa S. Spectrum of bacteria associated with diabetic foot ulcer and biofilm formation: A prospective study. Australas Med J. 2015;8(9):280-5.

17. Lipsky BA, Berendt AR, Cornia PB, Pile JC, Peters EJ, Armstrong DG, et al. 2012 Infectious Diseases Society of America clinical practice guideline for the diagnosis and treatment of diabetic foot infections. Clin Infect Dis. 2012;54(12):e132-73.

18. Garcia-Morales E, Lazaro-Martinez JL, Aragon-Sanchez J, Cecilia-Matilla A, Garcia-Alvarez Y, Beneit-Montesinos JV. Surgical complications associated with primary closure in patients with diabetic foot osteomyelitis. Diabet Foot Ankle. 2012;3.

19. He BB, Xu M, Wei L, Gu YJ, Han JF, Liu YX, et al. Relationship between Anemia and Chronic Com- plications in Chinese Patients with Type 2 Diabetes Mellitus. Arch Iran Med. 2015;18(5):277-83.

20. Desormais I, Aboyans V, Bura A, Constans J, Cambou JP, Messas E, et al. Anemia, an independent predictive factor for amputation and mortality in patients hospitalized for peripheral artery disease. Eur J Vasc Endovasc Surg. 2014;48(2):202-7.

21. Abreu KC, Motta EAP, Lima GO. Prevalência dos fatores de risco em pacientes com nefropatia diabética atendidos em um centro de referência em nefrologia do estado do Maranhão. Rev Ciênc Saúde. 2014;16(2).

22. Akha O, Kashi Z, Makhlough A. Correlation between amputation of diabetic foot and nephropathy. Iran J Kidney Dis. 2010;4(1):27-31.

23. Shojaiefard A, Khorgami Z, Larijani B. Independent risk factors for amputation in diabetic foot. Int J Diabetes Dev Ctries. 2008;28(2):32-7.

24. Brasileiro JL, Oliveira WTP, Monteiro LB, Chen J, Pinho Jr EL, Molkenthin S, et al. Pé diabético: aspectos clínicos. J Vasc Br. 2005;4(1):11-21.

Received in: 01/10/2016

Accepted for publication: 01/12/2016

Conflict of interest: none.

Source of funding: none.

\section{Mailing address:}

Natália Anício Cardoso

E-mail: natyanicio@hotmail.com 